\title{
Estimation of Armington Elasticities: An Application to the Philippines*
}

\author{
Cezary A. Kapuscinski and Peter G. Warr \\ Department of Economics, \\ Research School of Pacific and Asian Studies, \\ Australian National University
}

\begin{abstract}
The elasticities of substitution between imported and domestically produced goods Armington elasticities - are estimated in this paper for the Philippines. The estimated elasticities are intended for use in a large, empirically based computable general equilibrium model of the Philippine economy. Armington elasticities are known to be important for the properties of these models but are seldom estimated empirically. The results of this paper suggest that estimation is possible for developing countries, like the Philippines, for which economic data are generally considered poor, provided appropriate account is taken of the dynamic properties of the data.
\end{abstract}

JEL Classification Code: C5, F1.

Keywords: Computable General Equilibrium models, cointegrating models, Armington elasticities, international trade, the Philippines.

\footnotetext{
*The authors are grateful to Will Martin for discussions on an earlier draft and Apple Cruz, William Mudd and Zhong Ping Pulley for research assistance in collection and preparation of the data. Financial support was received from the Australian Centre for International Agricultural Research.
} 


\section{Introduction}

Empirical estimates are presented in this paper for the elasticities of substitution in demand between the imported and domestically produced forms of over 30 tradeable commodities in the Philippines. These so-called Armington elasticities (after Armington, 1969) are based on the differentiation of products with respect to their origin and the imperfect substitution in demand between imports and domestic supply. ${ }^{1}$ The estimates of these parameters are intended for use in a 50 sector computable general equilibrium (CGE) model of the Philippine economy, known as APEX. ${ }^{2}$ Models of this kind are widely used for policy analysis in both developed and developing countries but the parameters used within them seldom possess a solid empirical basis. This is especially true of Armington elasticities, even though the properties of CGE models are known to be sensitive to the values of these parameters. This paper thus attempts to contribute towards improving the empirical foundations of these models.

The economy of the Philippines, alongside other Southeast Asian economies, exhibited relatively high growth rates in the two decades preceding the 1973-74 oil price shock. Since then the economic performance of the Philippines has been well below the Southeast Asian average. Throughout this period, however, the Philippines has remained an open economy with the share of imports in GDP increasing from under 20 per cent in the early 1970s to over 25 per cent in the early 1990s.

With the successful conclusion of the Uruguay Round of the GATT in 1994 the Philippines, like many other developing countries, is now under pressure to reduce its average rates of protection under the agreement. Analysis of the economic effects of reduced protection is consequently of great policy interest in the Philippines. The degree to which imported and domestically produced goods substitute for one another in demand is central to such an analysis. The values of the parameters representing the rate at which this substitution occurs are thus highly relevant for empirical inquiry.

The remainder of the paper has five sections. Section II discusses the importance of Armington elasticities in CGE models. Section III outlines alternative methodologies

\footnotetext{
${ }^{1}$ See also Johnson, Grennes and Thursby (1979) for a discussion of product differentiation and its relevance for modelling international commodity trade.

${ }^{2}$ See Appendix A for a list of sectors in the APEX model and their mapping to the commodities appearing in Tables 1 to 6 .
} 
for estimation of Armington elasticities using time series data. Section IV discusses some data-related issues. The results are presented in Section V while Section VI concludes the paper.

\section{Theoretical Background}

In an open economy, each commodity can be differentiated according to its source of production: domestic and foreign (that is, imports). We shall assume that all supplies of a particular good originating domestically are identical, as viewed by purchasers of the good, and all foreign sources of that good are also regarded as identical. However, domestic goods and imports are considered different. Thus, domestic absorption consists of the demand for an aggregate of the domestic and imported product with the actual mix of the two commodities in the market place being determined by their relative prices and the degree of substitutability (or similarity) between them. The traditional trade-theoretic analysis of import demand is founded on the assumption of perfect substitution between domestic and imported goods, but this simplifying assumption is potentially misleading. It is unable to explain the observed continued demand for goods from both sources despite changes in their relative prices over time.

The degree of substitutability between domestic and imported sources of supply (or, conversely, the degree to which they are differentiated) is captured by the Armington elasticity. The higher the value of this parameter, the closer the degree of substitution. In other words, a high value of this parameter means that imports and domestic supplies are considered by purchasers to be virtually identical; they would be exactly identical if the parameter was infinite. On the other hand, a low value of the parameter means that the two products are dissimilar or, equivalently, that they are weak substitutes. Armington elasticities constitute a significant subset of the parameter space of the demand system. They play an important role in applied CGE modelling, especially for analyses directed at quantifying the economic effects of trade policies.

When the tariff applied to imports of a particular commodity is increased, this change raises the domestic price of the imported commodity (assuming no change in the exchange rate). Nevertheless, the effect that this change in the tariff has on the price of the domestically produced commodity is what determines its domestic resource allocation effects. If the imported and domestically produced goods are perfect substitutes, then the price of the domestically produced good will necessarily change 
by the same proportion as the price of the imported good. However, if the goods are imperfect substitutes, the price of the domestic good may not change by the same proportion as that of the import. Thus, the impact that changes in trade policy have on the structure of domestic production depends very much on the degree of substitutability between domestically produced and imported commodities, and this is what the Armington elasticity captures.

The above discussion assumes that all imported sources of a good are identical. They may, of course, be quite different. Models which differentiate all imports by country of origin have been developed, but these models usually cannot be implemented empirically because data on the quantities and prices of imported goods seldom identify them consistently and comprehensively by country of origin. The empirical literature - including the present paper - concentrates on the differentiation between domestic supplies and imports, rather than on the differentiation among imported supplies. An oversimplification is obviously involved in such an approach but it would seem of second-order of importance in most cases. The difference between domestic goods and imported goods seems likely to be greater than the differences among imports derived from different source countries.

The discussion also treats all domestic purchasers of particular goods as being identical in their demands and, in particular, in their assessment of the substitutability of imported and domestic supplies. The categories of domestic demand include final consumers, intermediate good purchasers, investment good purchasers and the government. These diverse domestic users of the good may all have different perceptions as to the degree to which domestic and imported supplies substitute for one another. Armington parameters could, in principle, be estimated separately for each of these levels of demand, but, again, available data can seldom sustain such an attempt. Empirical studies have thus normally had to rely on data relating to the aggregate demand for imported and domestically produced forms of individual goods, without distinguishing among the various levels of domestic demand.

There have been surprisingly few empirical estimates of Armington elasticities. Attempts at estimation were undertaken for various countries by Stern, Francis and Schumacher (1976). The resulting estimates varied widely, but centred around unity. Alaouze, Marsden and Zeitsch (1977) produced estimates for a few commodities for Australia, the estimates averaging around 2.0. Most CGE modelling studies have not undertaken direct estimation of Armington elasticities but have instead drawn heavily on these few very rough estimates. Default values, usually 2.0, have thus been used 
in many of these models (see, for example, Dixon, Parmenter, Sutton and Vincent, 1982; Dee, 1989; Martin, 1989).

A study by Shiells, Stern and Deardorff (1986) provided an indication of the likely problem with such 'best guess' values in the context of estimating substitution elasticities for disaggregated industries. In particular, they showed that an estimation procedure which takes account of potential econometric problems (such as dynamic mis-specification of the model) produces elasticity estimates significantly different from such 'best guess' values. More recently, Reinert and Roland-Holst (1992) presented estimates for 163 mining and manufacturing commodities in the United States based on extensive processing of detailed data bases from several US government departments and utilising a partial adjustment model.

Because of the data problems inherent in attempting to measure commodity or sectorspecific prices and quantities by origin, empirical estimation of Armington elasticities is recognised to be difficult (Abbott, 1988, Goldstein and Khan, 1985). Nevertheless, in view of the demonstrated importance of these parameters for the functioning of general equilibrium models (Pagan and Shannon, 1987), the lack of an adequate empirical basis for the values actually used in such models is unsatisfactory.

\section{Methodology}

Let $\mathrm{X}_{j}^{i}(t)$ and $\mathrm{X}_{j}^{d}(t)$ denote the quantity of imports and domestic production, respectively, of commodity $j$ at time $t$ and let $\mathrm{P}_{j}^{i}(t)$ and $\mathrm{P}_{j}^{d}(t)$ denote their respective price indices. The elasticity of substitution between imported and domestic goods for sector $j, \sigma_{j}$, can be defined as the proportionate change in the ratio of quantities divided by the proportionate change in the marginal rate of substitution in demand between these two goods. The CGE modelling approach we adopt assumes utility maximisation on the part of final consumers and cost minimisation on the part of intermediate good demanders and other users. Imposing this assumption during estimation permits use of the ratio of observed prices as a measure of the marginal rate of substitution. Thus, $\sigma_{j}$ can be written as:

$$
\sigma_{j}=\frac{\partial \log \left(\mathrm{X}_{j}^{i}(t) / \mathrm{X}_{j}^{d}(t)\right)}{\partial \log \left(\mathrm{P}_{j}^{d}(t) / \mathrm{P}_{j}^{i}(t)\right)}
$$

The form of the Armington demand function is clarified further by rewriting the variables of the demand system in proportional change form. Thus, suppressing the 
time variable $t$, the proportionate change in the demand for commodity $j$ from source $s$ (either imports $i$ or domestic supplies $d$ ) may be written as

$$
\mathrm{x}_{j}^{s}=\mathrm{x}_{j}^{*}-\sigma_{j}\left(\mathrm{p}_{j}^{s}-\sum_{g \in G} \mathrm{H}_{j}^{g} \mathrm{p}_{j}^{g}\right),
$$

where $s=i, d ; G=\{i, d\}$; and $j=1, \ldots, J$. Variables depicted in lower case Roman letters indicate proportional changes in the respective variables expressed in levels in equation (1). For example, $\mathrm{x}_{\mathrm{j}}=\mathrm{dX}_{\mathrm{j}} / \mathrm{X}_{\mathrm{j}}$. The variable $\mathrm{x}_{j}^{*}$ denotes the proportional change in the demand for the composite commodity $j$ and is to be considered exogenous in this discussion. The number of commodities is denoted by $J$, each of which exists in both a domestically produced and an imported form. Finally, $\mathrm{H}_{j}^{g}$ denotes the share of source $g$ (either domestically produced or imported) in total demand for $\operatorname{good} j$, where $\mathrm{H}_{j}^{d}+\mathrm{H}_{j}^{i}=1$.

The demand for domestic supplies $(s=d)$ becomes

$\mathrm{x}_{j}^{d}=\mathrm{x}_{j}^{*}-\sigma_{j}\left(\mathrm{p}_{j}^{d}\left(1-\mathrm{H}_{j}^{d}\right)-\mathrm{p}_{j}^{i} \mathrm{H}_{j}^{i}\right)$

But since $\mathrm{H}_{j}^{i}=1-\mathrm{H}_{j}^{d}$, equation (3) implies

$\mathrm{x}_{j}^{d}=\mathrm{x}_{j}^{*}-\sigma_{j} \mathrm{H}_{j}^{i}\left(\mathrm{p}_{j}^{d}-\mathrm{p}_{j}^{i}\right)=\mathrm{x}_{j}^{*}+\sum_{s \in G} \beta_{j}^{s} \mathrm{p}_{j}^{s}$

where $\beta_{j}^{d}=-\sigma_{j} \mathrm{H}_{j}^{i}$ and $\beta_{j}^{i}=\sigma_{j} \mathrm{H}_{j}^{i}$. Therefore, $\beta_{j}^{d}+\beta_{j}^{i}=0$, and, thus, in this two commodity case the Armington equation is equivalent to a flexible functional form demand equation which is homogenous of degree zero in the two commodity prices.

After some transformations of equation (1) we can arrive at the basic estimable relationship between quantities and prices:

$$
\log \left(\mathrm{X}_{j}^{i}(t) / \mathrm{X}_{j}^{d}(t)\right)=\alpha_{j}^{0}+\alpha_{j}^{1} \log \left(\mathrm{P}_{j}^{d}(t) / \mathrm{P}_{j}^{i}(t)\right)+u_{j}(t),
$$

where $\alpha_{j}^{0}$ is a constant of integration, $u_{j}(t)$ is a white noise error of the estimable model and the estimated value of $\sigma_{j}$ is given by the estimate of $\alpha_{j}^{1}$. Equation (5) can now be potentially employed in estimation of the $\sigma_{j}$ 's, given the appropriate data on prices and quantities. For convenience, we shall subsequently refer to it as the Ordinary Least Squares (OLS) model. 
Such a specification has, in fact, been estimated in an Australian study (Alaouze, Marsden and Zeitsch, 1977) as one of the alternative model formulations. The loglinear specification conforms with empirical tests of Khan and Ross (1977) and Boylan, Cuddy and O'Muircheartaigh (1980), among others, regarding the empirical specification of the aggregate import demand equation.

There are, however, two major reasons why equation (5) may not yield optimal estimates of the parameter of interest. First, being a static specification, this equation is not likely to capture adequately the dynamic relationships between imports, domestic production and prices. In particular, the process of adjusting the import/domestic product mix in response to price changes may not be complete within the period covered by a single data observation. The exclusion of relevant variables describing the dynamics of adjustment may, therefore, result in biased and inconsistent estimates of $\sigma_{j}$

Second, the quantity of imports entering a country is frequently subject to various regulations, such as tariffs or quantitative import restrictions, imposed by the government. In addition, short-run changes in the state of the domestic demand (or the level of the domestic capacity utilisation) may lead to changes in import demand which are (temporally) independent of relative prices. Such an outcome is especially common as a result of short-run domestic shortages or rationing of a particular commodity. Thus, the exclusion of this relevant information is again likely to bias the estimates of $\sigma_{j}$. Again, the study by Alaouze, Marsden and Zeitsch (1977), as well as that of Alaouze (1977), which used more aggregate data, illustrates the importance of such additional variables.

One procedure which overcomes the problem of incomplete adjustments in the markets relies on estimating a partial adjustment model (PAM):

$$
\begin{aligned}
\log \left(\mathrm{X}_{j}^{i}(t) / \mathrm{X}_{j}^{d}(t)\right)= & \beta_{j}^{0}+\beta_{j}^{1} \log \left(\mathrm{X}_{j}^{i}(t-1) / \mathrm{X}_{j}^{d}(t-1)\right)+ \\
& \beta_{j}^{2} \log \left(\mathrm{P}_{j}^{d}(t) / \mathrm{P}_{j}^{i}(t)\right)+u_{j}(t)
\end{aligned}
$$

The estimated short run value of $\sigma_{j}$ is given by the estimate of $\beta_{j}^{2}$. Such a model is derived from minimisation of a quadratic loss function (see, for example, Johnston, 1984) which attempts to capture costs to economic agents of adjusting quantities demanded in response to changes in prices. Although the partial adjustment model is an improvement on the static equation (5), the formulation of the estimable model in 
levels of variables is likely to lead to statistical problems such as high intercorrelations between regressors. Problems of this type occur frequently in econometrics because time series variables often trend together over time without necessarily implying any causal interrelationship.

An alternative method of overcoming the shortcomings of model (5) emphasises the time-series characteristics of variables and the dynamic specification of the estimable models. Thus, recent work by Engle and Granger (1987) has put forward a class of models, the error correction models (ECM), of the following form:

$$
\begin{aligned}
\Delta \log \left(\mathrm{X}_{j}^{i}(t) / \mathrm{X}_{j}^{d}(t)\right)= & \gamma_{j}^{0}+\gamma_{j}^{1} \Delta \log \left(\mathrm{P}_{j}^{d}(t) / \mathrm{P}_{j}^{i}(t)\right)+ \\
& \gamma_{j}^{2}\left[\log \left(\mathrm{X}_{j}^{i}(t-1) / \mathrm{X}_{j}^{d}(t-1)\right)-\log \left(\mathrm{P}_{j}^{d}(t-1) / \mathrm{P}_{j}^{i}(t-1)\right)\right]+ \\
& \gamma_{j}^{3} D_{j}+\gamma_{j}^{4} Z_{j}(t)+u(t)
\end{aligned}
$$

where $D_{j}(t)$ is a qualitative indicator (dummy variable) of trade restrictions in sector $j, Z_{j}(t)$ is a vector of other sector-specific indicators, such as the pressure of demand in sector $j$, and $\Delta$ indicates the difference operator. The estimated value of $\sigma_{j}$ is now given by the estimate of $\gamma_{j}^{1}$.

This type of model is based on the long-run relationship between variables. In particular, it is postulated that non-stationary variables may nevertheless form a stationary relationship in the long-run. Such a stable relationship, called the cointegrating relationship, often represents the long-run equilibrium postulated by economic theory. Thus, equation (7) reproduces in equilibrium the basic relationship defining the Armington elasticity, that is, equation (5). In addition, the ECM formulation and the cointegration of variables have been shown to be alternative manifestations of the same relationship (Engle and Granger, 1987). Finally, model (7) also has the desirable property of including both adjustments in import demand due to changes in relative prices and adjustments due to past disequilibria.

\section{Data Characteristics}

From the above discussion it is clear that a highly detailed data set is necessary for comprehensive estimation of the Armington elasticities for an economy-wide CGE model. Our data set comes from the National Statistics Office of the Philippines and other Philippine government institutions. ${ }^{3}$ The data cover time periods which vary

\footnotetext{
${ }^{3}$ See Appendix B at the end of this paper for the complete list of the sources of our data.
} 
somewhat for the different commodities studied but which span the period from the mid-1970s through to late 1980s for the majority of commodities. For the purposes of estimation we have constructed from the original annual time series of values and quantities a data set consisting of quantity and prices of imports and domestic production subdivided into sectors corresponding to the tradeables sectors of the APEX model. These data were then used to construct the required series of levels and proportionate changes in quantities and prices.

It was possible to assemble useable data for only 33 of the 42 tradeable commodities defined in APEX, partly because of problems with product classification and aggregation and partly because of non-availability of data. ${ }^{4}$ In particular, some goods, such as rice, were subject to stringent import restrictions and even total bans on importation for extended parts of the sample period and meaningful estimates of the elasticity of substitution for such commodities could not be obtained. The combined contribution of these nine omitted commodities to the 42-commodity totals of imports and domestic production were 5.5 per cent and 9.8 per cent, respectively.

Table 1 provides, in the first two columns, an overview of the relative importance for total consumption of each commodity of domestic production and import supply. Three commodities $(9,10$ and 28$)$ each contribute in excess of 10 per cent of the total domestic production of all 33 included commodities. The majority of other sectors each contribute between 0.1 per cent and 7 per cent, with only a few at the upper end of this range. On the import side, three commodities also stand out (11, 27 and 30). Clearly, importance in domestic production does not coincide with importance in total imports. For example, forestry accounts of 17 per cent of domestic production but only 0.06 per cent of imports while, conversely, crude oil accounts for over a quarter of total imports but just 0.03 per cent of domestic production.

[Table 1 about here]

\footnotetext{
${ }^{4}$ The nine omitted commodities/sectors and their sectoral codes within APEX are: sector 1 - irrigated rice; sector 2 - non-irrigated rice; sector 4 - coconut, including copra; sector 5 - sugarcane; sector 9 agricultural services; sector 15 - inland fishing; sector 29 - other made-up textile goods; sector 36 non-ferrous basic metal products; and sector 38 - semiconductors.
} 
In addition to the main quantity and price data it was possible to obtain data on two indicators of the presence of quantitative import restrictions. ${ }^{5}$ These data do not distinguish between tariff quotas or other non-tariff measures (such as import licensing or quota restriction) and identify only broad sectors rather than individual commodities which, with appropriate weighting, would have been a more appropriate measure of the severity of import restrictions. Nevertheless, the resulting dummy variables indicating the presence of either some restrictions to trade or complete bans affecting some commodities within each sector provide a potentially useful addition to the data set.

Table 2 summarises this information by presenting the proportion of each commodity's sample period during which either some trade restrictions or total bans were implemented, affecting some products within that commodity category. These data indicate a much greater variability in the extent of restrictions than bans as well as longer durations for restrictions than bans.

\section{[Table 2 about here]}

Before turning to estimation results we shall examine the stationarity properties of the data. This is important because recent econometric research (see, for example, Engle and Granger, 1987) suggests that the stationarity properties of economic time series have a significant bearing on the estimation of parameters. The investigation of the unit-root stationarity and the cointegration properties of the variables appearing on both sides of equation (5) permits a preliminary assessment of the suitability of the error correction model specification and may throw additional light on the dynamic behaviour of the quantities and prices of each commodity.

Our test results for stationarity and cointegration are summarised in Table 3. Given the small sample sizes available in our data base these results should be regarded as indicative only. 6 Nevertheless, an interesting picture does emerge. The overwhelming majority of the quantity and price series appear to be integrated of order one (that is, non-stationary). This suggests that the conventional estimation of Armington elasticities, based on OLS applied to equation (5) may lead to spurious

\footnotetext{
${ }^{5}$ Currently, the format of Philippine trade data does not permit the measurement of the share of commodities within each sector that are affected by trade restrictions.

${ }^{6}$ The critical values for these tests are approximate only. They are taken from Fuller (1976, p. 373), Dickey and Fuller (1981, p. 1063), and Sargan and Bhargava (1983, p. 157).
} 
results as a consequence of the trending behaviour of the underlying time series. Table 3 also indicates that the majority of commodities support a cointegrating relationship between the quantity and price variables, thus reinforcing the theoretical arguments supporting use of the ECM in estimating Armington elasticities.

[Table 3 about here]

\section{Results}

Estimates were obtained from three model specifications: ordinary least squares (OLS), the partial adjustment model (PAM), and the error correction model (ECM), which correspond to equations (5), (6) and (7) above, respectively. These basic model specifications provide the results shown in columns (1), (4) and (7), respectively, in Table 4. In addition, each of the three basic model specifications was augmented with a trade restriction dummy variable (columns (2), (5) and (9)) or with a trade ban dummy variable (columns (3), (6) and (10)). Finally (in column (8)), the basic ECM was also estimated in a restricted form with no constant term (that is, with the parameter $\gamma_{j}^{0}$ in equation (7) suppressed).

[Table 4 about here]

The complete set of estimated equations as well as their diagnostics are presented in a Statistical Appendix to this paper, available upon request. Table 4 summarises the main results by providing only the estimates of the commodity-specific Armington elasticities. Just over half of all $\sigma_{j}$ estimates are positive, as expected, and significant. About one-fifth of all estimates are negative, but none of these 'wrong' sign estimates are statistically significant.

Table 5 presents a brief summary of the fit of the estimated models. This table includes for each of the basic model types a measure of the fit $\left(\overline{\mathrm{R}}^{2}\right)$, a test for firstorder serial correlation and a general test for model mis-specification (Reset test). Clearly, the OLS and PAM specifications frequently resulted in major statistical deficiencies. On the other hand, the majority of the ECM models fit the data well and present no major statistical problems.

[Table 5 about here] 
The overwhelming majority of the significant estimates of $\sigma_{j}$ are either greater than unity or very close to it. This pattern can also be observed from Figure 1 which plots the estimated elasticities obtained from the basic model specifications (that is, without the trade restriction dummies) for all commodities. The significantly estimated elasticities for the basic ECM specification range from 0.2 for metal products (commodity 30) to 4.1 for sugar milling and refining (commodity 14) and they are spread evenly between agricultural and non-agricultural commodities.

[Figure 1 about here]

Closer examination of the diagnostic results reveals significant differences in the fit of the three models. ${ }^{7}$ In general, well-fitting models also produced significant estimates of the elasticities of substitution while poorly fitting models resulted in Armington elasticity estimates which were either insignificant or of the wrong sign. In addition, models from the latter category showed deficiencies in several areas such as misspecification of the regression equation, lack of stability or residual autocorrelation. ${ }^{8}$

A simple correlation comparison across commodities of the estimated elasticities produced by the alternative model specifications suggested that the highest correlations across model specifications were obtained from the models incorporating the trade restriction dummy. The correlation coefficients for the vectors of elasticities were 0.967 (OLS : PAM pair), 0.957 (OLS : ECM pair) and 0.979 (PAM : ECM pair). Corresponding correlation coefficients for the basic model specification were 0.963, 0.763 and 0.778 , respectively, and, for the specification with the trade ban dummy, 0.950, 0.906, and 0.878, respectively.

Finally, it is notable that the ECM models that produced significant estimates of the elasticities of substitution were also able to explain up to 90 per cent of the variation in the differences of the dependent variable - a proportion which usually can be achieved only in equations explaining the levels of economic variables which are trending.

\footnotetext{
${ }^{7}$ See the Statistical Appendix to this paper, available upon request.

${ }^{8}$ The results presented by Reinert and Roland-Holst (1992) also indicate that poorly fitting models provide imprecise estimates of Armington elasticities. In addition, some of their estimates also suffered from residual autocorrelation despite the use of the Cochrane-Orcutt procedure.
} 
To assess the estimated models further and to provide scope for testing their performance, non-nested tests have been performed on the three basic specifications which exclude the trade restrictions variables. In particular, the $\mathbf{J}$ test was utilised for pairwise model comparisons. This test relies on evaluating the usefulness of the predictions from the alternative model specification in the tested specification. ${ }^{9}$ The $\mathrm{J}$ test takes each of the three model specifications as the null hypothesis and thus provides an opportunity for each formulation to falsify its rivals. The outcomes of these tests are summarised in Table 6. The results provide significant support for our methodological arguments behind the need to use dynamic models in estimation of Armington elasticities. Thus, the OLS specification is rejected in a third of the commodities studied by the dynamic partial adjustment model but in over two-thirds of the cases by the error correction model. The PAM specification is also rejected by the theoretically superior ECM specification in over a third of the cases. On the other hand, the few rejections of the ECM specification are mostly at higher significance levels and, therefore, cannot be regarded as substantial evidence against the ECM specification.

[Table 6 about here]

Overall, the empirical results suggest that the basic ECM specification provides an adequate characterisation of the process of substitution between imports and domestic production. Its estimation yields statistically significant estimates of the Armington elasticities, suitable for use in further applied work such as that involving the use of the APEX model.

\section{Conclusions}

In this paper we have provided estimates of the elasticities of substitution between imported and domestically produced goods - Armington elasticities - for the Philippines. The elasticities are intended for use in a large, empirically based computable general equilibrium (CGE) model of the Philippine economy. We have discussed some econometric issues associated with the estimation of these elasticities and compared alternative model specifications according to their statistical adequacy. The stationarity properties of the time series data used for estimation and a comparison of the estimated models strongly suggested the error correction model as

\footnotetext{
${ }^{9}$ For a presentation of the principles and techniques of non-nested testing of models see, for example, McAleer (1987).
} 
the most appropriate specification. The estimated elasticities of substitution range from 0.2 for metal products to 4 for sugar milling and refining with a majority of these estimated elasticities greater than unity.

Armington elasticities are known to be important for the properties of CGE models. Nevertheless, builders of such models seldom estimate these parameters empirically, preferring to borrow from the handful of estimates available in the literature. These estimates usually relate to countries other than those represented by the CGE models into which the parameters are to be included and often also relate to levels of commodity aggregation and definition quite different from those characterising the CGE models concerned. Many of the estimates available in the literature also suffer from statistical deficiencies in estimation, especially as regards their dynamic features.

Limited resources are often available for econometric research and, to this extent, compromises are inevitable. But the reasons cited for compromises as to the empirical basis for the parameters used in CGE models also frequently include "lack of data". The results of this paper suggest that estimation is possible for developing countries, like the Philippines, for which economic data are generally considered poor. The available time series data present genuine problems. Nevertheless, provided appropriate account is taken of the dynamic properties of the data, they are still capable of sustaining empirical estimation of Armington elasticities. 
Appendix A: Sectoral identification in the APEX model.

\begin{tabular}{|c|l|c|}
\hline $\begin{array}{c}\text { Commodity } \\
\text { No. }\end{array}$ & Commodity/sector & $\begin{array}{c}\text { APEX sectoral } \\
\text { code }\end{array}$ \\
\hline 1 & Corn & 3 \\
2 & Banana \& other fruits \& nuts & 6 \\
3 & Vegetables & 7 \\
4 & Rootcrops & 8 \\
5 & Other commercial crops & 10 \\
6 & Hogs & 11 \\
7 & Chicken \& poultry products & 12 \\
8 & Other livestock & 13 \\
9 & Marine fishing & 14 \\
10 & Forestry \& logging & 16 \\
11 & Crude oil, coal \& natural gas & 17 \\
12 & Other mining & 18 \\
13 & Rice \& corn milling & 19 \\
14 & Sugar milling \& refining & 20 \\
15 & Milk \& dairy products & 21 \\
16 & Oils \& fats & 22 \\
17 & Meat \& meat products & 23 \\
18 & Flour milling & 24 \\
19 & Animal feeds & 25 \\
20 & Other foods & 26 \\
21 & Beverages \& tobacco & 27 \\
22 & Textile \& knitting mills & 28 \\
23 & Garments \& footwear & 30 \\
24 & Wood products & 31 \\
25 & Paper products & 32 \\
26 & Fertilizer & 33 \\
27 & Other rubber \& chemical products & 34 \\
28 & Coal \& petroleum products & 35 \\
29 & Cement \& non-metallic minerals & 37 \\
30 & Metal products \& non-electrical machinery & 39 \\
31 & Electrical machinery, equipment \& parts & 40 \\
32 & Motor vehicles & 42 \\
33 & Miscellaneous manufacturing & \\
& & \\
\hline
\end{tabular}




\section{Appendix B: Data Sources}

\section{Imports - quantities and values}

National Statistics Office, Foreign Trade Statistics of the Philippines 1977 to 1989, Manila.

\section{Domestic production - quantities and values}

Bureau of Agricultural Statistics, Statistics on Selected Major Crops 1981-1990, Manila.

Bureau of Agricultural Statistics, Selected Statistics on Agriculture, Manila (various years).

Bureau of Agricultural Statistics, Selected Fishery Statistics 1981-1990, Manila.

Department of Environment and Natural Resources, Mines and Geosciences Bureau, Minerals Statistics, Manila (various years).

Department of Environment and Natural Resources, Forest Management Bureau, Philippine Forestry Statistics, Manila (various years).

Bureau of Agricultural Statistics, Unpublished data, Department of Agriculture, Manila.

\section{Non-tariff measures}

De dios, L., 1986, Non-Tariff Measures Affecting Philippine Imports, Tariff Commission - Philippine Institute of Development Studies Joint Research Project, Staff Paper Series No. 86-10, Manila.

De dios, L., 1990, Philippine Non-Tariff Measures Updated to July 1990, unpublished data.

Tariff Commission of the Philippines, International Trade Branch, Philippine NonTariff Measures as of February 1990, Manila, unpublished data.

Central Bank of the Philippines, Memoranda to Authorized Agent Banks, Manila, (various years).

Central Bank of the Philippines, Various circulars, Manila, various years.

\section{Tariffs}

Tariff Commission of the Philippines, Harmonized Commodity Description and Coding System of the Philippines, Manila.

Tariff Commission of the Philippines, Unpublished data, Manila. 


\section{References}

Abbott, P.C., 1988, Estimating US agricultural demand elasticities: Econometric and economic issues, in: C.A. Carter and W.H. Gardiner, eds., Elasticities in International Agricultural Trade, (Westview Press, Boulder, Colorado).

Alaouze, C.M., 1977, Estimates of the elasticity of substitution between imported and domestically produced goods classified at the input-output level of aggregation, Working Paper No 0-13 (Industries Assistance Commission, Melbourne).

Alaouze, C.M., J.S. Marsden and J. Zeitsch, 1977, Estimates of the elasticity of substitution between imported and domestically produced commodities at the four digit ASIOC level, Working Paper No 0-11 (Industries Assistance Commission, Melbourne).

Armington, P.S., 1969, A theory of demand for products distinguished by place of production, IMF Staff Papers, 16, 159-178.

Boylan, T.A., M.P. Cuddy and I. O'Muircheartaigh, 1980, The functional form of the aggregate import demand equation: A comparison of three European economies, Journal of International Economics, 10, 561-566.

Dickey, D.A. and W.A. Fuller, 1979, Distribution of the estimators for autoregressive time series with a unit root, Journal of the American Statistical Association, 74, 427431.

Dickey, D.A. and W.A. Fuller, 1981, Likelihood ratio statistics for autoregressive time series with a unit root, Econometrica, 49, 1057-1072.

Dee, P.S., 1989, FH-ORANI: A Fiscal ORANI with Horridge Extension.' IMPACT Preliminary Working Paper No. OP-66, (University of Melbourne, Melbourne).

Dixon, P.B., B.R. Parmenter, J. Sutton and D.P. Vincent, 1982, ORANI: A Multisectoral Model of the Australian Economy, (North-Holland, Amsterdam).

Engle, R.F. and C.W.J. Granger, 1987, Cointegration and error correction representation, estimation, and testing, Econometrica, 55, 251-276.

Fuller, W.A., 1976, Introduction to Statistical Time Series, (John Wiley and Sons, New York).

Goldstein, M. and M. Khan, 1985, Income and price elasticities in international trade, in: R.W. Jones and P.B. Kenen, eds., Handbook of International Economics, Vol. 2, (North-Holland, Amsterdam) 149-160.

Johnson, P.R., T. Grennes and M. Thursby, 1979 , Trade models with differentiated products, American Journal of Agricultural Economics, 61, 120-127.

Johnston, J., 1984, Econometric Methods, (McGraw-Hill, New York, 3rd edition). 
Khan, S. and K. Z. Ross, 1977, The functional form of the aggregate import demand equation, Journal of International Economics, 7, 149-160.

Martin, W.J., 1989, Textiles and the foreign exchange regime. Paper presented at East Asia and Redirection of World Trade in Fibres, Textiles and Clothing Conference organised by Australian-Japan Research Centre, Australian National University, Canberra. 7-8 August, 1989.

McAleer, M., 1987, Specification tests for separate models: A survey, in: M.L. King, and D.E.A. Giles, eds., Specification Analysis in the Linear Model, (Routledge and Kegan Paul, London), 146-196.

Pagan, A.R. and J.H. Shannon, 1987, How reliable are ORANI conclusions?, Economic Record, 63, 33-45

Ramsey, J.B., 1969, Tests for specification errors in classical linear least-squares regression analysis, Journal of the Royal Statistical Society, Series B, 31, 350-371.

Reinert, K.A. and D.E. Roland-Holst, 1992, Armington Elasticities for United States Manufacturing Sectors, Journal of Policy Modelling, 14(5), 631-639.

Sargan, J.D. and A. Bhargava, 1983, Testing residuals from least squares regression for being generated by the Gaussian random walk, Econometrica, 51 (1), 153-174.

Shiells, C. R., R.M. Stern and A.V. Deardorff, 1986, Estimates of the elasticities of substitution between imports and home goods for the United States, Weltwirtschaftliches Archiv, 22, 497 - 519.

Stern, R. M., J. Francis and B. Schumacher, 1976, Price Elasticities in International Trade: An Annotated Bibliography, (Macmillan, London). 
Table 1: Summary of the commodity/sector characteristics.

\begin{tabular}{|c|c|c|c|c|}
\hline \multirow[t]{2}{*}{ No. } & \multirow[t]{2}{*}{ Commodity/sector } & \multicolumn{3}{|c|}{ Contribution (in \%) to total: } \\
\hline & & $\begin{array}{l}\text { Domestic } \\
\text { production }\end{array}$ & Imports & $\begin{array}{c}\text { Sectoral value } \\
\text { added }\end{array}$ \\
\hline 1 & Corn & 2.78 & 0.46 & 2.29 \\
\hline 2 & Banana \& other fruits \& nuts & 4.13 & 0.09 & 3.58 \\
\hline 3 & Vegetables & 0.98 & 0.17 & 2.39 \\
\hline 4 & Rootcrops & 1.44 & 0.01 & 1.08 \\
\hline 5 & Other commercial crops & 2.35 & 4.10 & 1.52 \\
\hline 6 & Hogs & 3.91 & 0.03 & 2.66 \\
\hline 7 & Chicken \& poultry products & 5.58 & 0.06 & 2.35 \\
\hline 8 & Other livestock & 1.30 & 0.02 & 0.80 \\
\hline 9 & Marine fishing & 10.61 & 0.24 & 5.41 \\
\hline 10 & Forestry \& logging & 17.25 & 0.06 & 2.97 \\
\hline 11 & Crude oil, coal \& natural gas & 0.03 & 26.20 & 0.51 \\
\hline 12 & Other mining & 7.04 & 1.53 & 3.11 \\
\hline 13 & Rice \& corn milling & 0.40 & 0.00 & 10.08 \\
\hline 14 & Sugar milling \& refining & 3.54 & 0.16 & 1.56 \\
\hline 15 & Milk \& dairy products & 0.95 & 2.02 & 1.45 \\
\hline 16 & Oils \& fats & 3.40 & 0.76 & 3.67 \\
\hline 17 & Meat \& meat products & 0.46 & 0.14 & 5.13 \\
\hline 18 & Flour milling & 2.24 & 0.69 & 0.77 \\
\hline 19 & Animal feeds & 0.79 & 1.41 & 2.15 \\
\hline 20 & Other foods & 0.79 & 0.25 & 6.37 \\
\hline 21 & Beverages \& tobacco & 2.21 & 0.25 & 5.69 \\
\hline 22 & Textile \& knitting mills & 0.48 & 8.80 & 1.86 \\
\hline 23 & Garments \& footwear & 0.38 & 0.34 & 2.98 \\
\hline 24 & Wood products & 1.95 & 0.57 & 2.35 \\
\hline 25 & Paper products & 0.69 & 0.17 & 2.02 \\
\hline 26 & Fertilizer & 0.52 & 2.18 & 0.81 \\
\hline 27 & Other rubber \& chemical products & 6.35 & 13.68 & 5.89 \\
\hline 28 & Coal \& petroleum products & 11.69 & 3.71 & 9.66 \\
\hline 29 & Cement \& non-metallic minerals & 3.85 & 5.79 & 3.50 \\
\hline 30 & Metal products \& non-electrical machinery & 0.57 & 10.66 & 2.60 \\
\hline 31 & Electrical machinery, equipment \& parts & 1.16 & 8.83 & 1.33 \\
\hline 32 & Motor vehicles & 0.12 & 2.43 & 0.74 \\
\hline 33 & Miscellaneous manufacturing & 0.07 & 4.21 & 0.65 \\
\hline
\end{tabular}

Notes:

(i) The shares are calculated with respect to the total of all included commodities/sectors.

(ii) The calculations of the shares in output and in imports are sample averages. The calculations of shares of value added are based on 1985 Input-Output table for the Phillipines. 
Table 2: Summary of commodity trade restrictions and bans.

\begin{tabular}{|c|c|c|c|}
\hline \multirow[t]{2}{*}{ No. } & \multirow[t]{2}{*}{ Commodity/sector } & \multicolumn{2}{|c|}{ Percentage of sample } \\
\hline & & under restriction & under bans \\
\hline 1 & Corn & 20.0 & 40.0 \\
\hline 2 & Banana \& other fruits \& nuts & 20.0 & 30.0 \\
\hline 3 & Vegetables & 40.0 & 40.0 \\
\hline 4 & Rootcrops & 30.0 & 40.0 \\
\hline 5 & Other commercial crops & 50.0 & 30.0 \\
\hline 6 & Hogs & 81.8 & 0.0 \\
\hline 7 & Chicken \& poultry products & 22.2 & 22.2 \\
\hline 8 & Other livestock & 54.5 & 0.0 \\
\hline 9 & Marine fishing & 54.5 & 27.3 \\
\hline 10 & Forestry \& logging & 22.2 & 22.2 \\
\hline 11 & Crude oil, coal \& natural gas & 33.3 & 22.2 \\
\hline 12 & Other mining & 100.0 & 0.0 \\
\hline 13 & Rice \& corn milling & 0.0 & 100.0 \\
\hline 14 & Sugar milling \& refining & 33.3 & 22.2 \\
\hline 15 & Milk \& dairy products & 22.2 & 0.0 \\
\hline 16 & Oils \& fats & 44.4 & 22.2 \\
\hline 17 & Meat \& meat products & 33.3 & 22.2 \\
\hline 18 & Flour milling & 33.3 & 22.2 \\
\hline 19 & Animal feeds & 77.8 & 0.0 \\
\hline 20 & Other foods & 33.3 & 22.2 \\
\hline 21 & Beverages \& tobacco & 33.3 & 22.2 \\
\hline 22 & Textile \& knitting mills & 22.2 & 22.2 \\
\hline 23 & Garments \& footwear & 22.2 & 22.2 \\
\hline 24 & Wood products & 33.3 & 22.2 \\
\hline 25 & Paper products & 22.2 & 22.2 \\
\hline 26 & Fertilizer & 33.3 & 0.0 \\
\hline 27 & Other rubber \& chemical products & 77.8 & 22.2 \\
\hline 28 & Coal \& petroleum products & 100.0 & 0.0 \\
\hline 29 & Cement \& non-metallic minerals & 66.7 & 22.2 \\
\hline 30 & Metal products \& non-electrical machinery & 55.6 & 22.2 \\
\hline 31 & Electrical machinery, equipment \& parts & 55.6 & 22.2 \\
\hline 32 & Motor vehicles & 66.7 & 33.3 \\
\hline 33 & Miscellaneous manufacturing & 55.6 & 22.2 \\
\hline
\end{tabular}

Notes:

(i) The proportions are based on commodity-specific data samples.

(ii) The periods of restrictions and bans were taken as the most intensive periods of trade impediments. 
Table 3: Results of tests of stationarity and cointegration on quantities and prices.

\begin{tabular}{|c|c|c|c|c|c|c|c|c|}
\hline \multirow[t]{3}{*}{ Commodity No. } & \multicolumn{6}{|c|}{ Stationarity tests } & \multicolumn{2}{|c|}{ Cointegration tests } \\
\hline & \multicolumn{3}{|c|}{ Qunatity variable } & \multicolumn{3}{|c|}{ Price variable } & \multirow[b]{2}{*}{ CR-DW } & \multirow[b]{2}{*}{$\mathrm{ADF}$} \\
\hline & $\mathrm{ADF}$ & $\mathrm{F}(2)$ & $\mathrm{F}(3)$ & $\mathrm{ADF}$ & $\mathrm{F}(2)$ & $\mathrm{F}(3)$ & & \\
\hline 1 & 0.504 & 2.197 & 2.967 & -3.194 & 4.512 & 5.117 & 0.713 & -0.810 \\
\hline 2 & -2.980 & 3.231 & 4.800 & -2.161 & 1.864 & 2.691 & 2.403 & -3.014 \\
\hline 3 & -3.541 & 6.147 & 7.483 & -2.760 & 2.639 & 3.952 & 0.959 & -2.013 \\
\hline 4 & -1.880 & 1.294 & 1.852 & -1.591 & 1.037 & 1.396 & 1.700 & -2.062 \\
\hline 5 & -1.921 & 1.242 & 1.856 & -2.104 & 1.598 & 2.281 & 2.677 & -3.769 \\
\hline 6 & -0.976 & 2.960 & 4.028 & -1.945 & 1.725 & 2.251 & 0.956 & -1.447 \\
\hline 7 & -0.568 & 0.740 & 0.834 & -1.023 & 0.817 & 1.097 & 0.605 & -0.601 \\
\hline 8 & -1.613 & 2.566 & 1.473 & -1.906 & 2.126 & 1.850 & 1.425 & -2.392 \\
\hline 9 & -2.002 & 1.577 & 2.333 & -1.831 & 1.385 & 1.812 & 0.688 & -1.317 \\
\hline 10 & -1.411 & 2.422 & 3.044 & -2.940 & 9.535 & 8.980 & 1.329 & -1.357 \\
\hline 11 & -3.034 & 68.701 & 102.077 & -3.587 & 8.619 & 12.357 & 1.209 & -2.786 \\
\hline 12 & -9.765 & 46.843 & 50.162 & -1.598 & 4.619 & 1.310 & 3.228 & -6.527 \\
\hline 13 & -3.212 & 5.773 & 6.401 & -2.707 & 2.577 & 3.710 & 1.337 & -3.117 \\
\hline 14 & -2.896 & 3.010 & 4.195 & -2.193 & 2.066 & 2.404 & 1.706 & -2.121 \\
\hline 15 & -2.208 & 14.937 & 20.230 & -6.479 & 37.105 & 50.329 & 1.542 & -1.661 \\
\hline 16 & -1.483 & 0.871 & 1.267 & -2.742 & 2.526 & 3.763 & 3.028 & -4.423 \\
\hline 17 & -0.916 & 1.299 & 1.441 & -1.775 & 2.110 & 3.068 & 1.810 & -2.561 \\
\hline 18 & -8.275 & 23.442 & 34.968 & -3.382 & 5.010 & 7.119 & 1.123 & -4.392 \\
\hline 19 & -0.186 & 2.151 & 2.471 & -1.828 & 1.118 & 1.672 & 1.049 & -1.334 \\
\hline 20 & -3.563 & 4.307 & 6.366 & -0.418 & 6.144 & 9.189 & 1.557 & -1.787 \\
\hline 21 & -1.377 & 1.186 & 1.705 & -1.955 & 1.817 & 2.456 & 2.477 & -2.956 \\
\hline 22 & -2.410 & 2.627 & 3.572 & -1.292 & 2.086 & 2.613 & 0.510 & -0.790 \\
\hline 23 & -1.928 & 1.326 & 1.935 & -6.746 & 31.086 & 26.104 & 2.073 & -2.374 \\
\hline 24 & -1.330 & 2.254 & 3.149 & -4.729 & 23.346 & 29.857 & 2.263 & -3.576 \\
\hline 25 & -2.122 & 1.815 & 2.619 & -1.431 & 1.413 & 1.775 & 3.123 & -5.582 \\
\hline 26 & -2.326 & 1.841 & 2.748 & -1.140 & 1.089 & 1.042 & 2.044 & -2.287 \\
\hline 27 & -5.015 & 9.158 & 12.631 & -3.371 & 5.424 & 6.391 & 2.328 & -2.676 \\
\hline 28 & -2.908 & 3.783 & 5.135 & -1.802 & 1.309 & 1.897 & 2.141 & -2.490 \\
\hline 29 & -6.748 & 17.159 & 25.656 & -2.997 & 3.078 & 4.608 & 1.103 & -1.303 \\
\hline 30 & -1.982 & 1.403 & 1.970 & -1.324 & 0.825 & 1.098 & 0.980 & -1.585 \\
\hline 31 & -1.391 & 1.278 & 1.791 & -2.092 & 1.484 & 2.226 & 1.681 & -6.981 \\
\hline 32 & -1.737 & 1.565 & 2.162 & -2.686 & 3.811 & 3.727 & 1.539 & -1.761 \\
\hline 33 & -2.460 & 2.352 & 3.498 & -2.442 & 2.211 & 3.316 & 2.904 & -7.438 \\
\hline
\end{tabular}

Notes:

(i) ADF, F(2) and F(3) are the unit root tests (see Dickey and Fuller, 1979, 1981). CR-DW is cointegration test based on the Durbin-Watson statistic (Engle and Granger, 1987).

(ii) The critical values at the 5\% level are: for stationarity tests (sample size $=25$ ): $\mathrm{ADF}=-3.6, \mathrm{~F}(2)=5.6, \mathrm{~F}(3)$ $=7.2$; for cointegration tests (sample size $=21$ ): $\mathrm{CR}-\mathrm{DW}=1.0, \mathrm{ADF}=-1.9$. 
Table 4: Summary of the estimates of the Armington elasticities.

\begin{tabular}{|c|c|c|c|c|c|c|c|c|c|c|}
\hline \multirow[t]{2}{*}{ Commodity No. } & \multicolumn{10}{|c|}{ Model specification } \\
\hline & $\begin{array}{l}\text { OLS } \\
\text { (1) }\end{array}$ & $\begin{array}{l}\text { OLS+Rest. } \\
\text { (2) }\end{array}$ & $\begin{array}{c}\text { OLS+Ban } \\
\text { (3) }\end{array}$ & $\begin{array}{l}\text { PAM } \\
\text { (4) }\end{array}$ & $\begin{array}{c}\text { PAM+Rest. } \\
\text { (5) }\end{array}$ & $\begin{array}{c}\text { PAM+Ban } \\
\text { (6) }\end{array}$ & $\begin{array}{c}\text { ECM } \\
(7)\end{array}$ & $\begin{array}{c}\text { Rest'd ECM } \\
(8)\end{array}$ & $\begin{array}{c}\text { ECM+Rest. } \\
(9)\end{array}$ & $\begin{array}{c}\mathrm{ECM}+\mathrm{Ban} \\
\text { (10) }\end{array}$ \\
\hline 1 & $3.784 *$ & $3.897^{*}$ & $3.768^{*}$ & 4.798* & $4.759^{*}$ & $4.916^{*}$ & $3.715^{*}$ & $3.707^{*}$ & $3.692 *$ & $3.784 *$ \\
\hline 3 & $1.497^{*}$ & 1.081 & $1.238^{*}$ & $1.187^{*}$ & $1.161^{*}$ & $1.155^{*}$ & 0.722 & 0.803 & 0.650 & 0.751 \\
\hline 4 & 0.205 & -0.508 & 0.350 & 0.388 & -0.709 & 0.843 & -1.086 & 1.139 & -0.616 & -1.153 \\
\hline 5 & 0.067 & -0.133 & 0.101 & 0.028 & -0.230 & 0.080 & -0.056 & 0.060 & -0.037 & -0.058 \\
\hline 8 & $1.892 *$ & $1.717 *$ & n.a. & $1.583^{*}$ & $1.537 *$ & n.a. & $1.320 *$ & $1.396^{*}$ & $1.458^{*}$ & n.a. \\
\hline 9 & 1.038 & 0.479 & 1.444 & $1.881^{*}$ & $1.758^{*}$ & $2.064 *$ & 1.060 & 1.046 & $1.341 *$ & 1.021 \\
\hline 10 & $0.752 *$ & $0.684^{*}$ & $0.807 *$ & $0.761 *$ & $0.700^{*}$ & $0.888^{*}$ & $0.829^{*}$ & $0.819^{*}$ & $0.798^{*}$ & $0.908^{*}$ \\
\hline 11 & $1.240^{*}$ & $1.132 *$ & $1.004^{*}$ & $0.728^{*}$ & $0.729^{*}$ & $0.677^{*}$ & $0.650^{*}$ & $0.742 *$ & $0.688^{*}$ & $0.673^{*}$ \\
\hline 12 & $0.525^{*}$ & n.a. & n.a. & $0.912 *$ & n.a. & n.a. & $1.111^{*}$ & $1.036^{*}$ & n.a. & n.a. \\
\hline 13 & 2.051 & n.a. & n.a. & 1.525 & n.a. & n.a. & 0.614 & 0.776 & n.a. & n.a. \\
\hline 18 & 0.254 & $0.455^{*}$ & 0.409 & 0.412 & $0.917 *$ & 0.971 & $0.722 *$ & $0.725^{*}$ & $0.735^{*}$ & $0.697 *$ \\
\hline 19 & 0.447 & -0.159 & n.a. & 0.304 & -0.156 & n.a. & -0.224 & -0.140 & 0.259 & n.a. \\
\hline 20 & -0.035 & -0.057 & -0.102 & -0.088 & -0.090 & -0.125 & 0.112 & 0.107 & 0.133 & 0.101 \\
\hline 21 & $1.069^{*}$ & 0.491 & $0.876^{*}$ & $1.024 *$ & 0.418 & $0.875^{*}$ & 0.324 & 0.314 & 0.343 & 0.326 \\
\hline 22 & 0.111 & 0.322 & 0.134 & 0.180 & 0.437 & 0.559 & $0.651^{*}$ & $0.642 *$ & $0.728^{*}$ & $0.691 *$ \\
\hline 23 & 0.038 & 0.008 & 0.286 & 0.136 & 0.090 & 0.307 & 0.241 & 0.134 & 0.149 & 0.236 \\
\hline 24 & -0.032 & -0.115 & -0.156 & -0.097 & -0.148 & -0.247 & -0.013 & -0.013 & 0.064 & -0.042 \\
\hline 25 & $0.740^{*}$ & $0.667 *$ & $0.778^{*}$ & $0.813^{*}$ & $0.740 *$ & 0.701 & $0.600 *$ & $0.570^{*}$ & $0.610^{*}$ & $0.652^{*}$ \\
\hline 26 & -0.520 & -0.233 & -0.233 & -0.525 & 0.243 & 0.243 & -0.223 & -0.175 & 0.207 & 0.207 \\
\hline 27 & -0.148 & -0.149 & -0.118 & -0.146 & -0.151 & -0.119 & -0.680 & -0.069 & -0.080 & -0.070 \\
\hline 28 & 3.062 & n.a. & n.a. & 3.019 & n.a. & n.a. & 0.558 & 0.497 & n.a. & n.a. \\
\hline 29 & 0.417 & 0.346 & 0.419 & 0.383 & 0.349 & 0.395 & $0.587 *$ & $0.560^{*}$ & $0.641 *$ & $0.679^{*}$ \\
\hline 32 & $2.047^{*}$ & $1.880^{*}$ & 1.634 & $1.952 *$ & $1.879^{*}$ & 1.617 & $2.006^{*}$ & $1.863^{*}$ & $1.968^{*}$ & $2.148^{*}$ \\
\hline 33 & $1.045^{*}$ & $1.058^{*}$ & $1.027 *$ & $1.053^{*}$ & $1.069^{*}$ & $1.024 *$ & $1.043^{*}$ & $1.047 *$ & $1.046^{*}$ & $0.984 *$ \\
\hline
\end{tabular}

Notes:

(i) Significance level of $10 \%$ or better is indicated with an asterisk.

(ii) "n.a." indicates model specifications which could not be estimated because the restrictions/bans covered the entire estimation period. 
Table 5: Summary of diagnostics of the estimated basic model specifications.

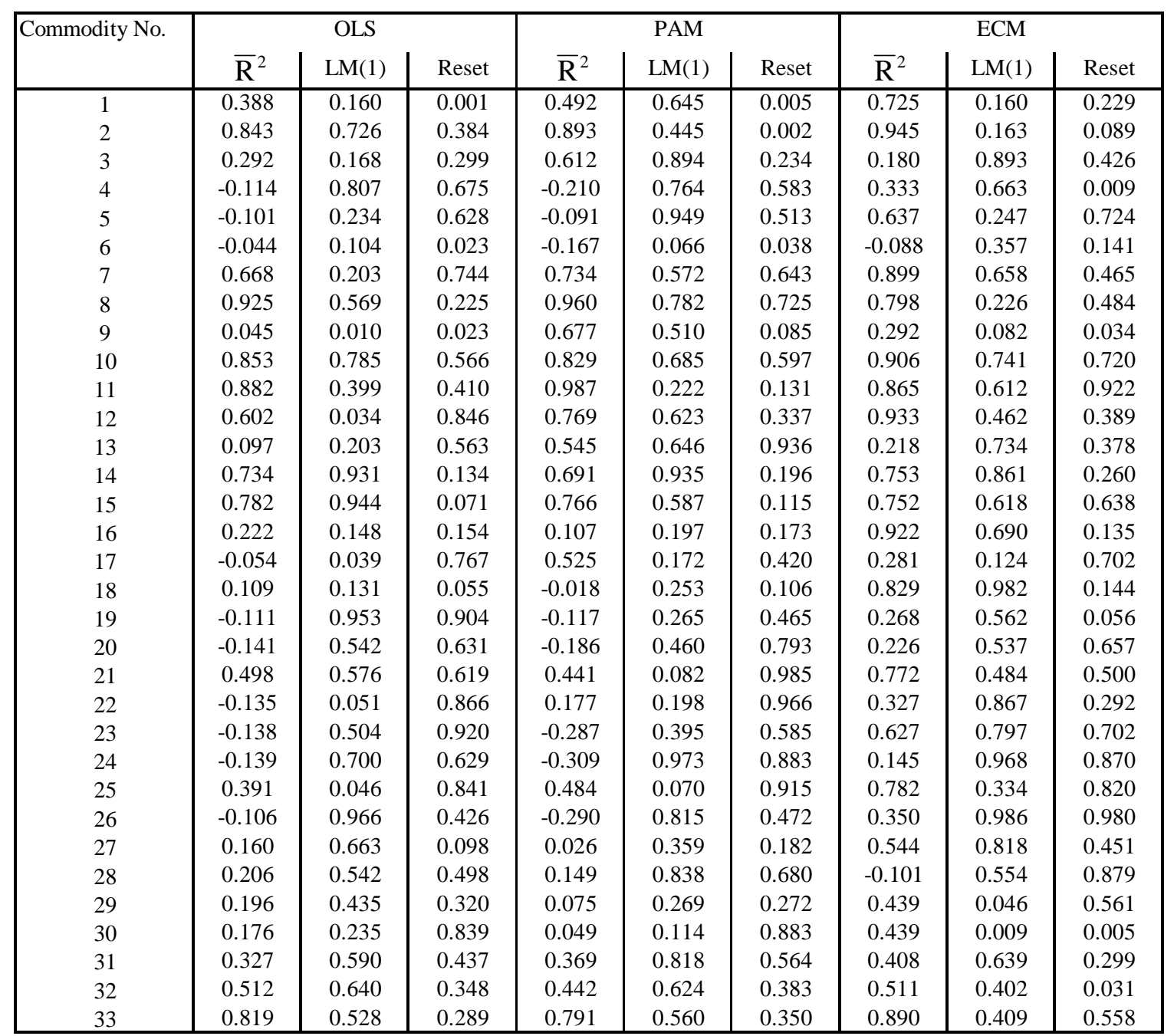

Notes:

(i) $\overline{\mathrm{R}}^{2}$ is the adjusted regression coefficient of determination $\left(\mathrm{R}^{2}\right)$.

(ii) $\operatorname{LM}(1)$ is the Lagrange Multiplier test for first order serial correlation. The entries in the table are the Marginal Significance Levels of the test statistics.

(iii) Reset is Ramsey's (1969) test for regression misspecification. The entries in the table are the Marginal Significance Levels of the test statistics. 
Table 6: Results of the non-nested tests on basic model specifications.

\begin{tabular}{|c|c|c|c|c|c|c|c|c|c|c|c|c|}
\hline \multirow[t]{3}{*}{ Commodity No. } & \multicolumn{4}{|c|}{ H0: OLS model } & \multicolumn{4}{|c|}{ H0: PAM model } & \multicolumn{4}{|c|}{ H0: ECM model } \\
\hline & \multicolumn{2}{|c|}{ H1: PAM } & \multicolumn{2}{|c|}{ H1: ECM } & \multicolumn{2}{|c|}{ H1: OLS } & \multicolumn{2}{|c|}{ H1: ECM } & \multicolumn{2}{|c|}{ H1: OLS } & \multicolumn{2}{|c|}{ H1:PAM } \\
\hline & J-test & MSL & J-test & MSL & J-test & MSL & J-test & MSL & J-test & MSL & J-test & MSL \\
\hline 1 & 1.623 & 0.074 & 1.625 & 0.074 & 0.121 & 0.454 & 0.523 & 0.310 & 0.626 & 0.277 & 0.636 & 0.274 \\
\hline 2 & 2.185 & 0.033 & 5.253 & 0.001 & 0.003 & 0.499 & 3.545 & 0.006 & 1.585 & 0.082 & 1.601 & 0.080 \\
\hline 3 & 2.757 & 0.014 & 2.315 & 0.027 & 0.725 & 0.246 & 1.250 & 0.129 & 0.786 & 0.231 & 0.530 & 0.308 \\
\hline 4 & 0.607 & 0.282 & 1.549 & 0.083 & 0.975 & 0.181 & 1.286 & 0.123 & 0.953 & 0.189 & 0.108 & 0.459 \\
\hline 5 & 1.037 & 0.167 & 1.542 & 0.084 & 0.122 & 0.453 & 1.005 & 0.177 & 0.258 & 0.403 & 0.506 & 0.316 \\
\hline 6 & 0.216 & 0.417 & 0.202 & 0.423 & 0.929 & 0.190 & 0.046 & 0.482 & 0.390 & 0.354 & 1.107 & 0.152 \\
\hline 7 & 1.648 & 0.075 & 3.698 & 0.005 & 1.068 & 0.163 & 2.533 & 0.026 & 1.019 & 0.177 & 1.098 & 0.161 \\
\hline 8 & 3.008 & 0.008 & 1.558 & 0.079 & 1.669 & 0.067 & 1.111 & 0.152 & 0.502 & 0.315 & 0.380 & 0.358 \\
\hline 9 & 4.311 & 0.001 & 4.268 & 0.001 & 2.215 & 0.029 & 0.860 & 0.209 & 2.483 & 0.021 & 2.629 & 0.017 \\
\hline 10 & 0.212 & 0.420 & 1.483 & 0.094 & 0.582 & 0.291 & 1.336 & 0.120 & 0.321 & 0.381 & 0.323 & 0.380 \\
\hline 11 & 7.714 & 0.000 & 7.346 & 0.000 & 0.235 & 0.411 & 0.526 & 0.311 & 1.609 & 0.084 & 1.550 & 0.091 \\
\hline 12 & 2.464 & 0.024 & 5.695 & 0.001 & 0.570 & 0.295 & 4.329 & 0.004 & 1.074 & 0.166 & 0.690 & 0.260 \\
\hline 13 & 2.809 & 0.015 & 2.923 & 0.013 & 0.530 & 0.308 & 0.487 & 0.324 & 0.632 & 0.278 & 0.644 & 0.274 \\
\hline 14 & 0.154 & 0.441 & 0.712 & 0.252 & 0.354 & 0.368 & 0.636 & 0.276 & 0.488 & 0.323 & 0.490 & 0.323 \\
\hline 15 & 0.737 & 0.245 & 1.690 & 0.071 & 0.114 & 0.457 & 1.372 & 0.114 & 1.489 & 0.098 & 1.221 & 0.138 \\
\hline 16 & 0.319 & 0.380 & 3.431 & 0.007 & 0.429 & 0.343 & 3.417 & 0.009 & 0.717 & 0.253 & 0.549 & 0.303 \\
\hline 17 & 3.088 & 0.011 & 3.039 & 0.011 & 0.315 & 0.382 & 0.294 & 0.390 & 0.498 & 0.320 & 0.425 & 0.344 \\
\hline 18 & 0.359 & 0.366 & 2.616 & 0.020 & 0.183 & 0.431 & 3.019 & 0.015 & 3.336 & 0.010 & 3.075 & 0.014 \\
\hline 19 & 0.981 & 0.182 & 2.021 & 0.045 & 0.420 & 0.345 & 1.501 & 0.097 & 0.493 & 0.321 & 0.193 & 0.427 \\
\hline 20 & 0.856 & 0.213 & 1.319 & 0.118 & 0.089 & 0.466 & 0.884 & 0.209 & 0.568 & 0.297 & 0.522 & 0.312 \\
\hline 21 & 0.534 & 0.306 & 2.180 & 0.036 & 0.473 & 0.326 & 1.887 & 0.059 & 0.359 & 0.367 & 0.309 & 0.385 \\
\hline 22 & 1.911 & 0.052 & 3.430 & 0.007 & 0.491 & 0.320 & 2.150 & 0.042 & 0.904 & 0.204 & 1.296 & 0.126 \\
\hline 23 & 0.435 & 0.340 & 2.028 & 0.044 & 0.078 & 0.470 & 1.796 & 0.066 & 0.335 & 0.376 & 0.303 & 0.387 \\
\hline 24 & 0.303 & 0.386 & 0.428 & 0.342 & 0.752 & 0.240 & 0.701 & 0.257 & 0.551 & 0.303 & 0.318 & 0.382 \\
\hline 25 & 1.507 & 0.091 & 1.994 & 0.047 & 0.929 & 0.194 & 1.183 & 0.145 & 1.176 & 0.146 & 1.413 & 0.108 \\
\hline 26 & 0.047 & 0.482 & 0.289 & 0.391 & 0.478 & 0.325 & 0.260 & 0.403 & 0.370 & 0.363 & 0.358 & 0.367 \\
\hline 27 & 0.192 & 0.427 & 1.367 & 0.110 & 0.253 & 0.404 & 1.265 & 0.131 & 0.666 & 0.267 & 0.668 & 0.267 \\
\hline 28 & 0.727 & 0.247 & 0.399 & 0.352 & 1.331 & 0.116 & 0.617 & 0.282 & 1.674 & 0.077 & 1.226 & 0.137 \\
\hline 29 & 0.298 & 0.388 & 1.259 & 0.127 & 0.051 & 0.480 & 1.109 & 0.159 & 0.231 & 0.413 & 0.233 & 0.413 \\
\hline 30 & 0.252 & 0.405 & 1.952 & 0.049 & 0.399 & 0.352 & 1.758 & 0.070 & 0.960 & 0.191 & 0.989 & 0.184 \\
\hline 31 & 1.210 & 0.136 & 2.097 & 0.040 & 0.815 & 0.223 & 3.827 & 0.006 & 0.147 & 0.445 & 0.673 & 0.265 \\
\hline 32 & 0.347 & 0.370 & 0.064 & 0.475 & 0.876 & 0.207 & 0.098 & 0.463 & 0.655 & 0.271 & 0.636 & 0.276 \\
\hline 33 & 0.254 & 0.404 & 0.540 & 0.304 & 0.163 & 0.438 & 0.444 & 0.338 & 0.060 & 0.477 & 0.059 & 0.478 \\
\hline
\end{tabular}

Notes:

(i) $\mathrm{H} 0$ indicates the null hypothesis being tested, $\mathrm{H} 1$ indicates the alternative model specification.

(ii) The test outcomes and their Marginal Significance Levels are given under the headings J-test and MSL, respectively. 
Figure 1: Estimated Armington elasticities (basic model specifications).

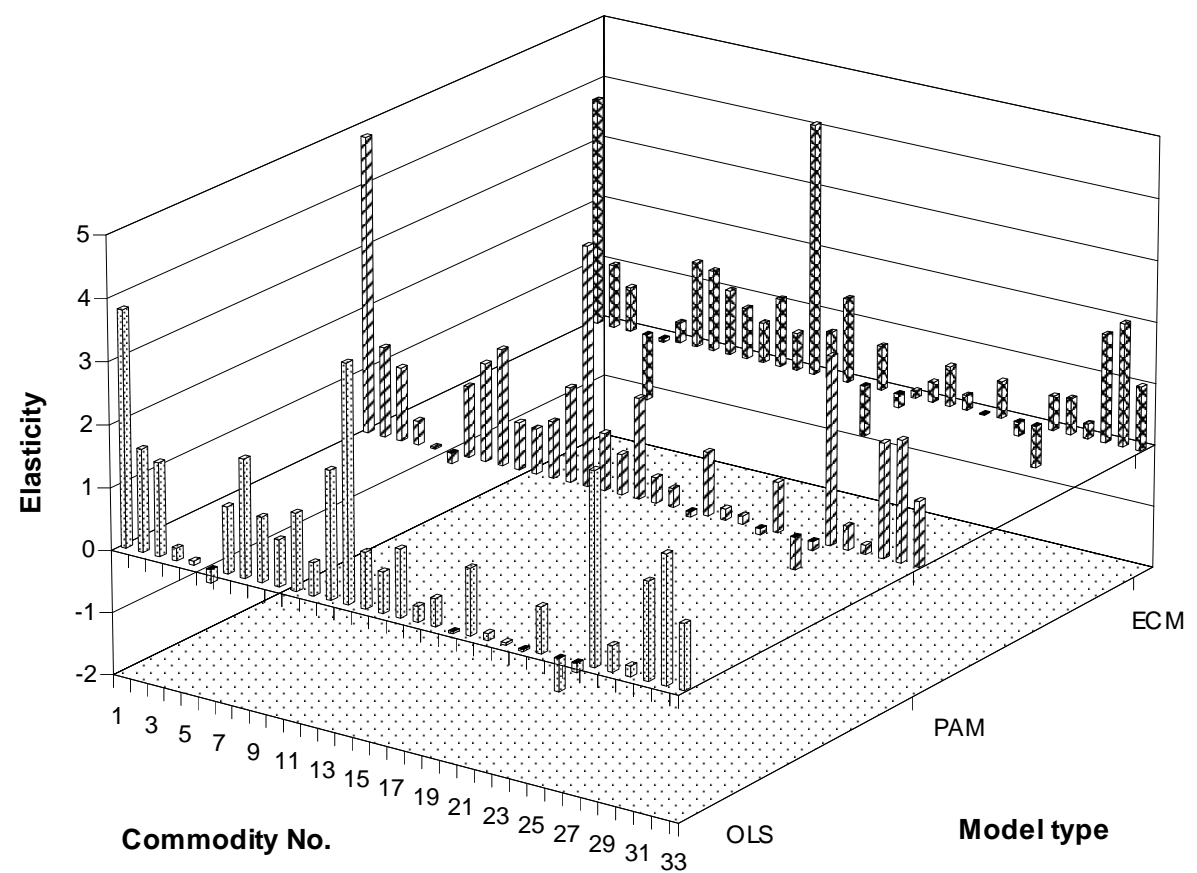

